\title{
THE SOUTH ATLANTIC CONVERGENCE ZONE: A CRITICAL VIEW AND OVERVIEW
}

Rubens Junqueira VILLELA

\begin{abstract}
The South Atlantic Convergence Zone (SACZ) is an elongated and persistent band of convection which in the summer season and fairly frequently extends itself from the Amazon to the ocean offshore the Brazilian coasts, playing a significant role in the country's rainfall regime. Together with its twins in the Pacific and Indian, it makes up a new category of large-scale meteorological organisms, identified from the 1970s through the analysis of satellite observations. The explanation for the phenomenon is still a challenge to meteorology and climatology; essentially, it results from an intense interaction between tropical and mid-latitude systems. In this paper, we review a part of the subject's history, including, besides Brazilian researchers's contributions, the providential Japanese studies comparing the SACZ with the Baiu, and present brief descriptions of SACZ events in Brazil. As a complement, we report ourselves to two events of destructive intense precipitation, of frontal nature, in São Paulo state, to be compared to SACZ action.
\end{abstract}

Keywords: SACZ; South America; Convergence Zone; Precipitation; Atmospheric systems.

\section{RESUMO}

A ZONA DE CONVERGÊNCIA DO ATLÂNTICO SUL, UMA VISÃO E REVISÃO CRÍTICAS. A Zona de Convergência do Atlântico Sul (ZCAS) é uma alongada e persistente banda de intensa convecção que na época de verão e com certa frequência se estende da Amazônia ao oceano ao largo das costas brasileiras, exercendo papel significativo no regime pluviométrico do País. Juntamente com suas congêneres do Pacífico e do Índico, constitui uma nova categoria de organismo meteorológico de larga escala, identificado a partir da década de 1970 através da análise de observações de satélite. A explicação do fenômeno é ainda um desafio para a meteorologia e climatologia; essencialmente, resulta de uma intensa interação entre sistemas tropicais e de latitude média. Neste trabalho, recapitulamos uma parte da evolução histórica dos conhecimentos sobre o assunto, incluindo, além das contribuições de pesquisadores brasileiros, os providenciais estudos japoneses comparando a ZCAS com a Baiu, e apresentamos descrições resumidas de eventos de ZCAS no Brasil. Como complemento, reportamo-nos a dois eventos de precipitações destrutivas no Estado de São Paulo, de natureza frontal, a comparar com a atuação da ZCAS.

Palavras-chave: ZCAS; América do Sul; Zona de Convergência; Precipitação; Sistemas atmosféricos.

Abbreviations used in this paper:

States of Brazil: AC - Acre, AM - Amazonas, BA - Bahia, ES - Espírito Santo, GO Goiás, MG - Minas Gerais, MS - Mato Grosso do Sul, MT - Mato Grosso, PA - Pará, PR - Paraná, RJ - Rio de Janeiro, RO - Rondônia, RS - Rio Grande do Sul, SC - Santa Catarina, SP - São Paulo, TO - Tocantins

BFZ: Baiu Frontal Zone

ITCZ: Intertropical Convergence Zone

SACZ: South Atlantic Convergence Zone / ZCAS: Zona de Convergência do Atlântico Sul SPCZ: South Pacific Convergence Zone 


\section{INTRODUCTION}

The term (in Portuguese) "Zona de Convergência do Attântico Sul" came to be a part of the Brazilian meteorological language - generally abbreviated ZCAS (SACZ - South Atlantic Convergence Zone - in English) and pronounced "zácas" - beginning in the 1980s. Its use in synoptics and in technical bulletins has become as common place as "cold front", "upper-level trough", "frontal wave", "extratropical cyclone", "tropical anticyclone", "baroclinic", "cold low", etc. - technical terms fundamental for physically describing relevant atmospheric phenomena or processes occurring in the country. In turn, SACZ, due to the close association of its Asiatic counterpart with the Indian monsoon, has contributed in recent years to the adoption of another new term in Brazilian meteorology: "South American monsoon system" (The elder idea of a South American monsoon was a cause for debate and generally rejected by climatology) (GAN et al. 2016).

The SACZ is essentially an extensive belt or persistent (quasi-stationary) convectively active cloud band, accompanied by abundant precipitation, occurring generally in the austral summer season and oriented northwest to southeast over the tropical region of South America and the adjacent South Atlantic Ocean. Operationally, in order to be named thus, the SACZ should last for at least 4 days. From the synoptic meteorology point of view, it is similar to a stationary or semistationary front (that is, an originally cold front which stalled), exhibiting convergent winds but without the density (or temperature) contrast between cold and warm air mass characterizing the classic fronts (NIETO-FERREIRA 2011, TARIFA \& AZEVEDO 2001, SATYAMURTI $\&$ RAO 1988). From the wider viewpoint of the general circulation of the atmosphere, the SACZ constitutes a new class of large-scale phenomena - the so-called "tropical convergence zones", which are four in the planet: the one of the South Pacific, of the Asiatic East (or Baiu in Japan), of the South Atlantic, and (the less expressive one) of the South Indian. These four convergence zones present common characteristics - the main one the moisture convergence (coming together of moist winds) in low levels - but also significant differences, some of them attributed to local or regional geographical factors (continental, maritime and orographic), others attributed to remote sources and propagated by the atmosphere itself through the so-called "teleconnections" (factors carried by global circulation systems such as Rossby waves and jet stream). These differences in characteristics - and even the fundamental characteristics of the "tropical convergence zone" phenomenon itself - are still poorly known and/ or poorly explained in the specialized literature, a fact which makes the subject rather complex.

In this article, besides a summary of knowledge about the subject and something about its historic evolution, and in view of its relevance for the understanding of this country's climate (especially its rainfall regime), we will try to contribute for a better understanding of the subject by the non-specialized reader. A full review of the concept here would be too long, and inconclusive, since the nature of the phenomenon has not been sufficiently elucidated yet. Moreover, there already is an excellent review by QUADRO et al. (2016) published in Climanálise, about SACZ studies carried out in Brazil and in other countries over the last 30 years.

\section{THE INTERTROPICAL CONVERGENCE ZONE AND THE POLAR FRONTS}

Satellite images, that became available from 1960 onwards, served to confirm in a clear and impacting way the existence of various kinds of cloud bands. In turn, the image composite analysis technique, by brightness or long wave radiation made possible to extract exact data about cloud band extension, intensity, persistence and other characteristics, such as their association with precipitation. An analysis of cloudiness by pentads, that is, 5-day mean images, allows for establishing a climatology of phenomena portrayed in the area, for example, the polar front position, frequency of meso-scale convective complexes, the Intertropical Convergence Zone oscillations, etc.

Among these bands, undoubtedly, the socalled Intertropical Convergence Zone (ITCZ) is one of the most remarkable phenomena observed in the Earth's atmosphere. Its role as an obstacle to marine and air navigation in historic times persist to present days, as an analysis of the well-known accident with the Air France flight 447 (Rio de Janeiro to Paris), over the Equatorial Atlantic, on June $1^{\text {st }}, 2009$, can show (VILLELA 2009). It consists, in general terms, in a belt of strong cloudiness, accompanied by frequent showers, 80 to $600 \mathrm{~km}$ wide and up to $18 \mathrm{~km}$ high, which surrounds the planet almost without a break, approximately along the equator. It separates the constant and humid trade winds of the Northern Hemisphere, which blow from the northeast, from the equally humid and constant 
trade winds of the Southern Hemisphere, from the southeast. Basically a product of solar heating and trade wind convergence, the ITCZ - differently from the SACZ - is relatively easy to explain as part of a Hadley cell within the general circulation system (e.g. SILVADIAS \& JUSTI DA SILVA 2009, Fig. 1.2, p. 17). As air is lifted in the equatorial zone by heating and convergence, it diverges aloft towards the subtropical high pressures, where it sinks, back to the surface, where it gets partly redirected back to the equator, closing the cell. But recent researches, based on the GATE World Meteorological Program in the Tropical Atlantic show failures in this explanation (FRANK 1983). The ascending motions, for instance, do not take place in a single cell as shown in climatological charts but are concentrated in a large number of cumulonimbi and their associated circulations. The confluence line of the winds at the surface does not coincide with the stronger convection line but, in the tropical Atlantic, lies from 100 to $200 \mathrm{~km}$ north of it. And the kinetic energy excess, generated by the direct circulation Hadley cell, in its greater part is exported meridionally in the high troposphere, not continuously but by transient eddies.

The ITCZ was formerly named "Intertropical Front", for a supposed analogy to polar fronts in the concept created by the "Bergen Norwegian school" (SANT'ANNA NETO 2015) by the time of the World War 1914-18. However "front" is reserved to the line (really an inclined surface) separating different density air masses, which is not the ITCZ case.

The frontal cloud bands shown by satellite images are an excellent confirmation for the Scandinavian school theories of polar fronts and associated extratropical cyclones. Frontal zones are one of the main precipitation producing systems in the Earth's atmosphere. The theory of atmospheric fronts is not always well understood by the nonspecialist. The existence in an equilibrium condition of a separation surface between a cold and a warm air mass in the shape of an inclined plan (in the classic model a wedge of cold and dry air lifts up the warm and moist air) is only possible because of the Earth's rotation (Coriolis effect), otherwise the colder air would just lie horizontally underneath the warm air (the condition is theoretically described by Margules' formula - SAUCIER 1969, which gives the front's slope in function of the temperature contrast between the air masses and the latitude). And in order to form a sharp zone of transition between cold air mass and warm air mass, there must be convergence between them; for instance, a wind from the north that brings the warm air together with the cold air to the south (in the Southern Hemisphere), otherwise the temperature transition from the cold to the warm air mass would be gradual and not in the form of a front (VILLELA 1972). When we taught Synoptic Meteorology at Instituto de Astronomia, Geofísica e Ciências Atmosféricas - USP, using radiosonde data, we had the students doing many thickness (given by the layer's mean temperature) graphical analysis exercises, as well as vertical cross sections, by tracing potential temperature isotherms, mixing ratio isolines, etc. (SAUCIER 1969, chapter 6, Cross Section Analyses). This type of analysis promotes the viewing of the three-dimensional structure of fronts and other weather systems, and for the student doing it by his own hands, amounts to doing his or hers own discovery of the atmosphere and of how it works.

\section{THE "DISCOVERY” OF THE SACZ AND ITS COUNTERPARTS}

The International Geophysical Year (195758) was marked by historical advancements in scientific knowledge of the Earth: knowledge of the meteorology of the Southern Hemisphere, previously lacking observations, was particularly benefited, with the occupation of posts in Antarctica and the launching of Sputnik, the first artificial satellite of the earth, followed by the meteorological satellites from 1960 onwards. The Australian Neil STRETEN (1973) saw in the images and radiation data obtained by the satellites, proofs of the existence of basically four long and persistent cloud bands across the Southern Hemisphere oceans (Figure 1). Streten's paper published in a Monthly Weather Review of 1973 raised much interest and constituted a basic reference for the research work on Antarctic meteorology I was carrying out at the time in IAGUSP, on a scholarship from the National Research Council (VILLELA 1975). We quote directly from this report to NRC, in view of its clarifying quality:

Initially, the Author [Streten] recalls that the bright bands of clouds extending either zonally or meridionally are one of the prominent aspects in the satellite photographs, be they daily or averaged over several days. The frequency and regularity of these bands in the Southern Hemisphere is particularly striking. He cites a paper by ERICKSON \& WINSTON (1972) which suggests that some kinds of bands are visual manifestation of channels for the transfer of energy in the form of heat and moisture from the tropics to higher latitudes. 
A previous study by the Author [Streten] for the Southern Hemisphere indicated that bands located in the average over fixed geographic areas, and generally frontal in nature and associated with cyclonic vortices, are due to regularity of the cyclone tracks and/or persistence of convergence zones in the low and middle levels of the troposphere. Seeking to relate the cloud band position to the westerly waves in the flow aloft, the Author takes in account studies that show a relation with (a) sea surface temperature, and (b) significant stationary components of wave numbers 3 and 4 of the westerly hemispheric waves. From the Author's fig. 1, reproduced in Annex 18 [of the report to NRC], we see that in November 1969 the semi-permanent band of the South Atlantic, between the southeastern coast of Brazil and the coast of Antarctica east of the Weddell Sea is associated with the leading edge of the mean trough in the 700 millibar level - a fact to be expected from the theoretical dynamic point of view (negative vorticity advection and resulting ascending motion ahead of the trough - RJV).

Basic data for the present Streten's study were the satellite photos (mean 5-day mosaics) for the period November 1968 to October 1971, for which only the positions of the most extensive and persistent mean bands were determined, during summer (December-March), intermediary seasons (April-May, October-November), and winter (JuneSeptember), and annually.

The Author concludes by saying that the nature of these cloud bands is still uncertain, but evidently they are closely related to the long-wave hemispheric pattern. He calls attention to the fact that ATS-3 pictures show cloud movement from the Amazon tropical region, towards the southeast, until entering the persistent band over the South Atlantic and the Antarctic. The process suggests that the bands are indeed mean channels of energy flow, created by active convection over tropical continents, and transferred to the zone of west winds in the

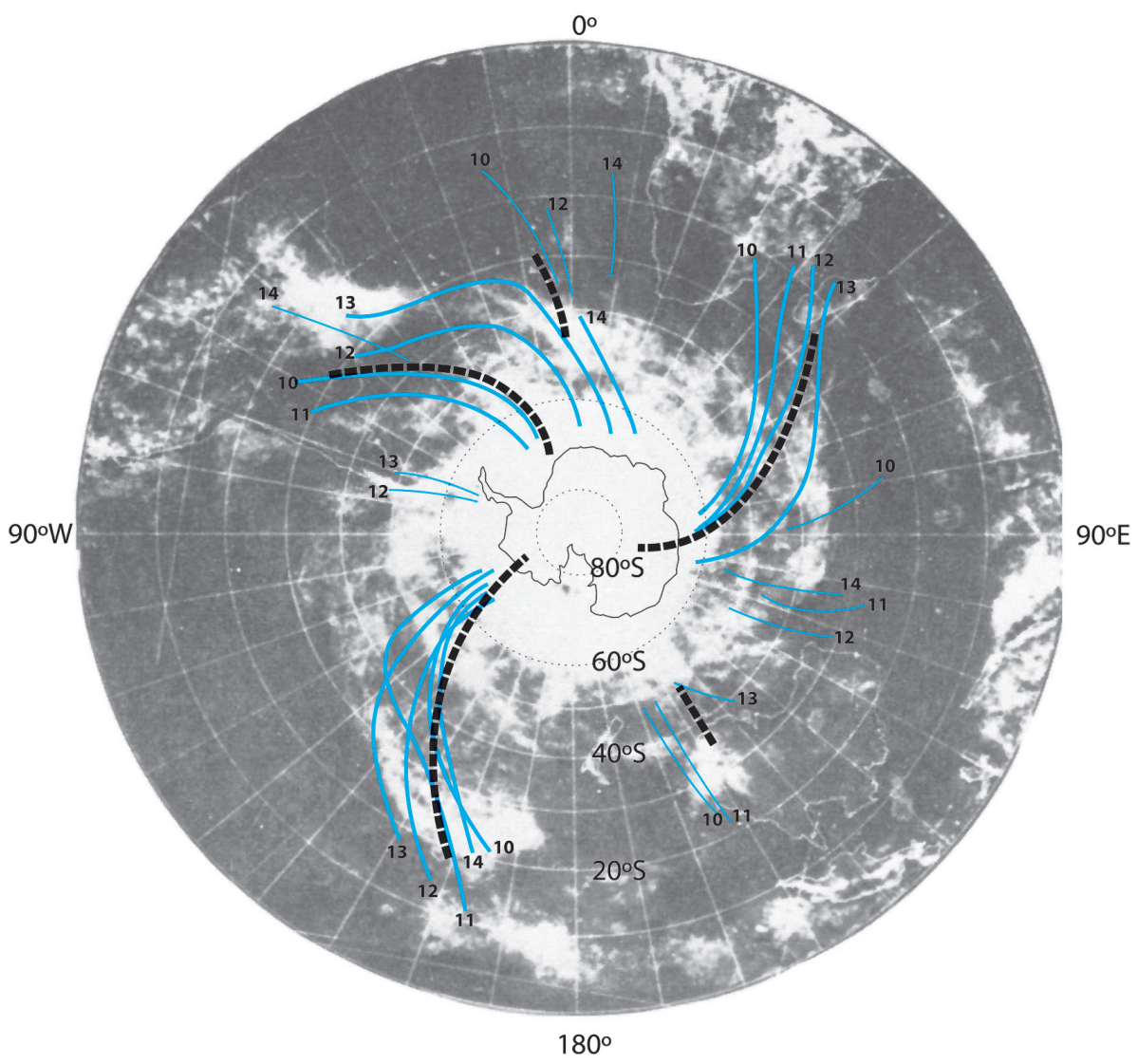

FIGURE 1 - Southern Hemisphere viewed by 5-day-averaged mosaic from Nov. 10-14, 1969 and location of $700 \mathrm{hPa}$ troughs in the long-wave, scale-separated components for corresponding indicated dates. Heavy blue lines represent well-defined troughs, fine blue lines represent minor troughs, and striped black lines represent troughs in the mean 5-day field. Adapted from STRETEN (1973). 
middle latitudes. There you have, in today's terms, a definition for the SACZ!

A small historical note: in 1960, for the first time in South America, we published a photograph from the Tiros satellite (Figure 2), which had been sent to us by Prof. Harry Wexler, U.S. Weather Bureau's scientific director (VILLELA 1960). Together with a copy of the surface synoptic chart we had analyzed in the meteorological department of Real-Aerovias airlines, the published image showed the relationship between a frontal band crossing the Andes and the presence of a jet stream in the high levels. I still owe to Dr. Wexler part of the support I got to participate in my first Antarctic expeditions, invited by the U. S. Navy and National Science Foundation, in the 196061 and 1961-62 seasons.
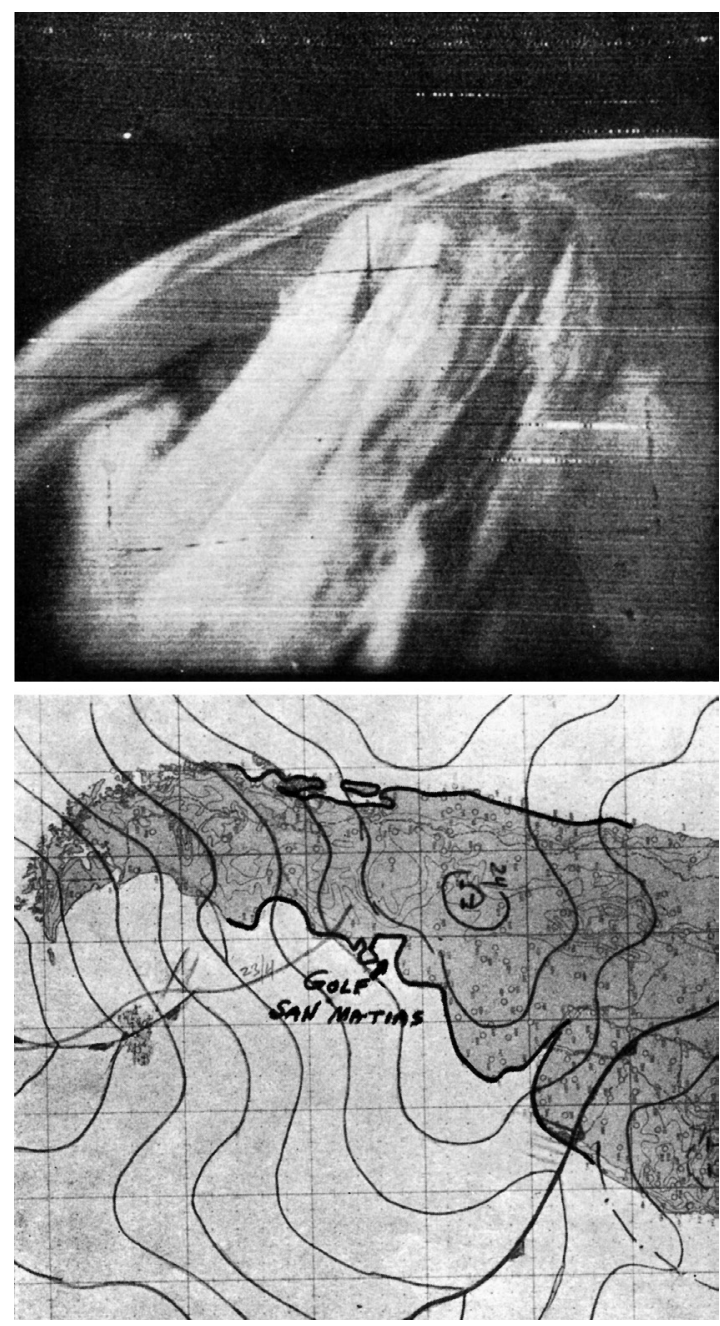

FIGURE 2 - Photograph from the Tiros satellite and the surface synoptic chart showing the relationship between a frontal band crossing the Andes and the presence of a jet stream in the high levels (Adapted from VILLELA 1960).

\section{COMPARISON BETWEEN BAIU AND SACZ}

A phenomenon typical of the rainy season which happens between May and July in China and Japan, the Baiu, or Mei-ju ("plum rains"), is a kind of semi-stationary front characterized by an extensive band of strong convective precipitation, when in its active phase (Glossary of Meteorology, AMERICAN METEOROLOGICAL SOCIETY, 2000, term South Atlantic convergence zone, p. 705). Naturally the Japanese meteorologists soon identified the great similarity of the Baiu with the bands described for other maritime regions, after Streten's pioneer work, already cited. Two authors of comparative studies and that at the same time help us to understand the SACZ distinguish themselves: Yasumasa Kodama $(1992,1993)$ and Kozo Ninomiya $(1984,2007)$.

KODAMA (1992) begins by recalling the importance of understanding rainfall distribution for agricultural productivity, whereas in general the subtropical zones are relatively dry although situated between more rainy zones: the polar front and ITCZ, and monsoons. He defends, with NINOMIYA (1984), classifying Baiu as a "subtropical frontal zone" - and goes on calling it "Baiu Frontal Zone" (BFZ), recalling that it, when active, produces almost as much rain as the ITCZ in the mean, $400 \mathrm{~mm}$ monthly. $\mathrm{He}$ makes then a comparison, using 10-day mean data, between BFZ, SPCZ (South Pacific Convergence Zone), and SACZ (South Atlantic Convergence Zone), considering the three zones as significant summer rainfall zones, having common characteristics.

Still according to KODAMA (1992), the BFZ activity varies during the season, and can present different precipitation mechanisms (convective, stratiform, "meso alfa" scale, etc.) but it is in its peak period that the most marked characteristics are present: the BFZ occurs then along the subtropical jet on the east side of a trough in the upper level westerly winds which remains semi-stationary ("anchored") west of Japan. This trough in turn lies to the northeast (in the Southern Hemisphere it would be to the southeast) of the most active convection zone of the tropical monsoon. At this point, KODAMA (1992) renders us one of the most important contributions for the understanding of SACZ, our version of the BFZ: he presents a conceptual model of the circulation around a Baiu Front (Figure 3), shown as in a synoptic 
chart and in a vertical cross-section, which let us visualize its structure and behavior (we note that to transfer a Northern Hemisphere circulation to the Southern Hemisphere the safest way is to turn the page upside down and look through it from the reverse side against the light to make it transparent). Thanks to a recent professional work, in which we made a weather forecast for Otsu (located next to Kyoto) (VILLELA 2017) asked for by a Japanese group, we had the opportunity to check Kodama's model in practice and follow the evolution on a Baiu event that affected the west of Japan in May 2017. Still in the beginning of the season, probably anticipated in consonance with equal anticipation of the Indian monsoon this year, the event produced $46 \mathrm{~mm}$ of precipitation in Kyoto on May 13, mostly in the form of showers, in less than 12 hours. The synoptic evolution seemed to us like the gradual passage from west to east of a weak frontal wave which in our region would possibly occur in the Atlantic Ocean offshore away from the Brazilian southeast coast, with E-component wind (originated from the subtropical high) ahead of the wave converging with $\mathrm{W}$-component wind (originated from mid latitude) behind the wave.

Kodama's further figures are also very revealing, showing by means of mean charts the distribution of atmospheric parameters such as temperature, wind, moisture, convergence, vertical velocities, etc. for the conditions in the three convergence zones studied comparatively. They constitute strong evidence of the similarities between the zones in different regions of the globe.

NINOMIYA (2007) also presents a comparison between SACZ and Baiu, however employing the results of a numerical simulation, and equally provides conceptual schemes of the two phenomena (his fig. 3, p. 281) (Figure 4), much elucidating. Ninomiya's conclusions coincide with Kodama's, but he highlights the following differences between SACZ and Baiu. A major one is obviously in the geographic context. The SACZ polar border is the "cold South Atlantic" which provides the significant baroclinicity, thus downslope or gradient for generating strong westerly winds, whereas Baiu's polar border is a warm continent, causing the weak baroclinicity of Baiu. While in Baiu more precipitation occurs on the polar side, this is not so in SACZ. Yet in Baiu, intense precipitation has a more complicated distribution than in SACZ; this according to Ninomiya, because really it does not seem so to us: in the SACZ, be its continental or oceanic branch (exhibiting different behaviors) the precipitation distribution also varies, not least under such influences as of sea surface temperatures, Decadal Oscillation, Madden-Julian Oscillation, low level jet, El Nino, La Niña, etc.
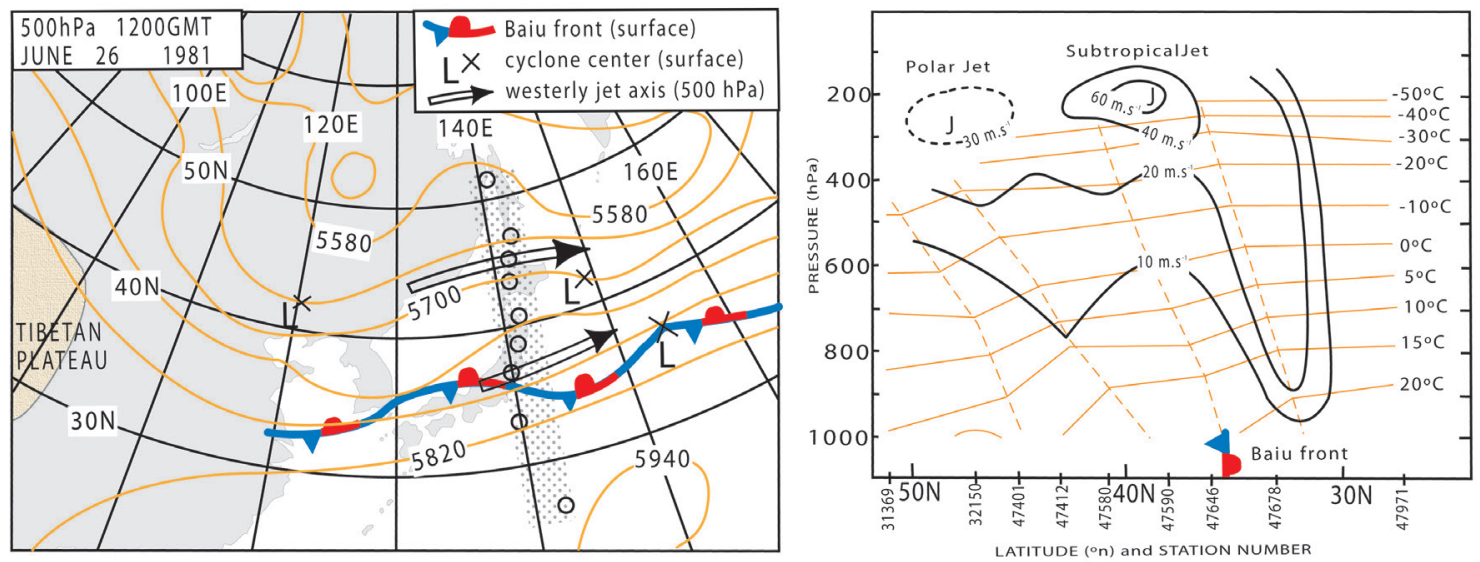

FIGURE 3 - Conceptual model of the circulation around a Baiu Front in a synoptic chart (left) and in a vertical cross-section (right). Adapted from KODAMA (1992). 

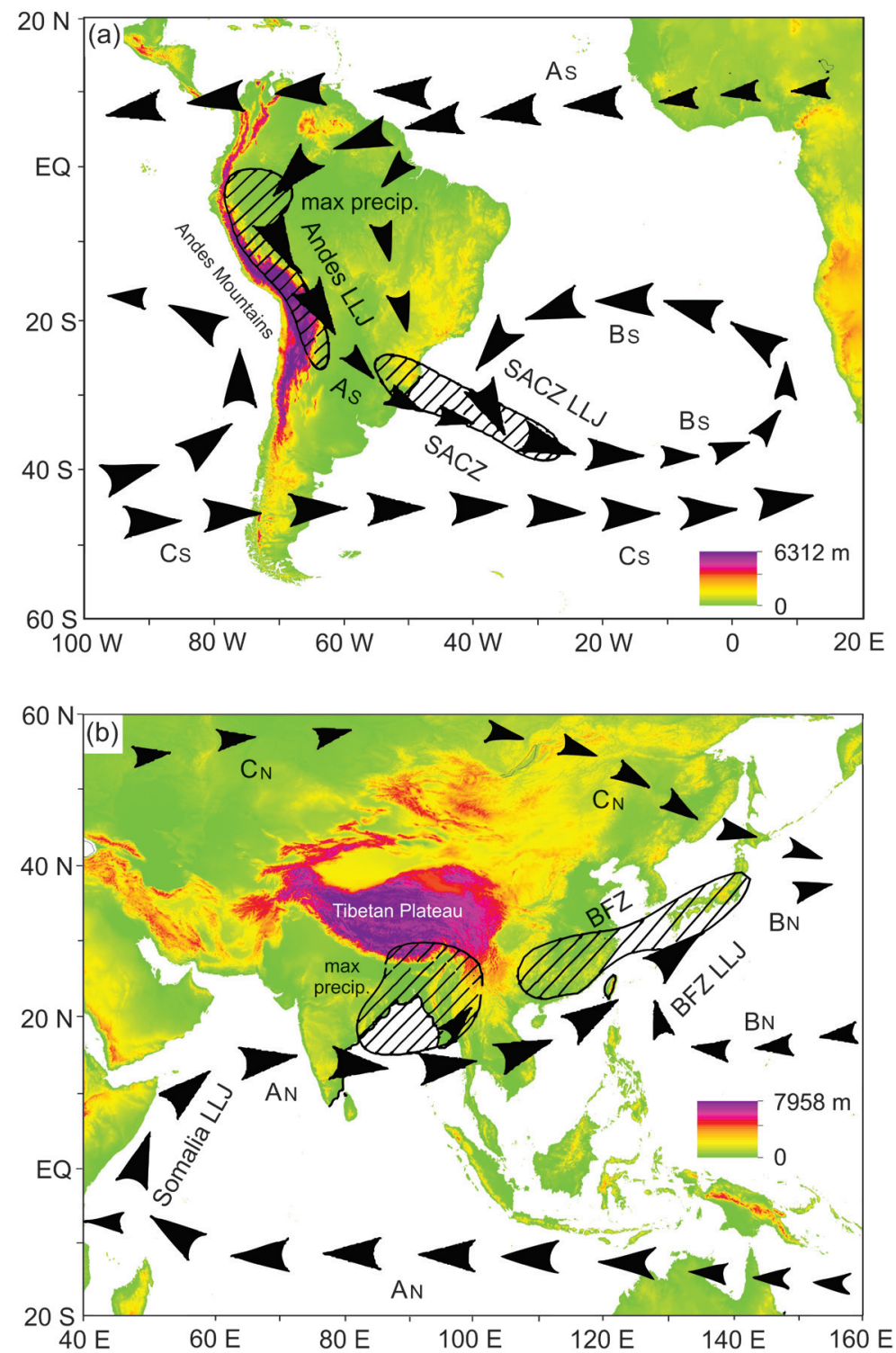

FIGURE 4 - Schematic illustrations of the basic features of the SACZ (a) and BFZ (b) simulated in the AGCM (Atmospheric General Circulation Model). As: anticlockwise gyre that originates from the Atlantic trade winds, Bs: anticyclonic circulation around the South Atlantic anticyclone, Cs: middle-latitude westerly winds, LLJ: low-level jet. Adapted from NINOMIYA (2007). Digital elevation model (DEM): Global 30 ArcSecond Elevation (GTOPO30) - available from the U.S. Geological Survey/NASA at https://earthexplorer.usgs.gov.

\section{SACZ RESEARCH IN BRAZIL}

The first references to the SACZ phenomenon in Brazilian meteorological literature date from 1986 (CASARIN \& KOUSKY 1986) and 1988 (CALHEIROS \& SILVA DIAS 1988,
SATYAMURTI \& RAO 1988). In CASARIN \& KOUSKY (1986), the reference appears in the English abbreviated form, SACZ (South Atlantic Convergence Zone). The 1988 reference appears in Climanálise, which is the monthly bulletin of climatic monitoring and analysis edited by CPTEC 
(see also QUADRO et al. 2016). However, it is worth mentioning that the first papers by Prof. Pedro L. da Silva Dias on the large-scale response of tropical circulation to intense convection - a process essential for the understanding of SACZ - date from 1983. Formation of the Bolivian High, which partakes of this process and was shown by Silva Dias to be mainly a product of heat of condensation liberated by Amazon convection in the summer (SILVA DIAS et al. 1983, SILVA DIAS 1985). Local heat from the high Andean plateau also contributes; air lifted by convection increases the pressure at upper levels. The Bolivian High (an extensive anticyclonic circulation in the high levels) in turn, in generating a trough to the east and a strongly divergent zone aloft in its southeast side, contributes to strengthening the SACZ or its anteceding fronts and making it stationary (CARVALHO \& JONES 2009). Note that the SACZ creates its own circulation which makes it self-sustaining and maintains the necessary continuous inflow of moisture: air which rises in the tall, deep convection returns in the manner of compensating descending currents in the north and south of precipitation zones, a fact which explains the subsidence zones at the margins of the SACZ: for instance, dry areas in Rio Grande do Sul (RS) and in Bahia (BA), accompanying a SACZ across southeastern Brazil (CASARIN \& KOUSKY 1986).

It is interesting to note how emphasis on certain terms has changed in the last few years, as climatological knowledge advanced: the Bolivian High came about to occupy the place formerly held by the Chaco Low, also a result of continental heating (in the lower levels) (SCHWERDTFEGER 1951). Nevertheless the Chaco Low keeps on being important, in relation to moisture transport, feeding rains in the south-central part of the continent, or for its association with the low level jet, another factor influencing the SACZ.

Climanálise is a synthetic and objective source, written in a technically precise and up-todate meteorological language, about the weather evolution in the country, month by month and inserted in the hemispheric, if not global, scale. For anyone who really wants to understand the SACZ (and other phenomena of comparable complexity), and perhaps feels lost in reading scientific papers, it is better to see how the phenomenon occurs and works in the real world as described in Climanálise. We did this exercise for several summer months (October to March 1996-2000) and brought out some interesting and actual information about SACZ, as follows (we use italics for emphasis). Surprisingly (and this could be disappointing), we found that in some months the SACZ "shines by being absent", that is, it is totally absent; a fact which never happens with the cold fronts, present up to 8 times or more a month, in Brazilian territory. However, an analysis of a longer series (1996-2013) (QUADRO et al. 2016, Fig. 1, p. 22) clearly shows an increasing frequency of the SACZ beginning in 2006. In these statistics, the SACZ occur in $29.8 \%$ of days in the period November to March, indicating that the SACZ was present approximately every three days in the season. Looking at this figure, we see that in 1996-2006 there were 10 to $50 \mathrm{SACZ}$ days, and in 2007-2013 there were 30 to $80 \mathrm{SACZ}$ days.

Following is a collection of summaries of monthly synoptic reports pertaining to SACZ episodes, taken from Climanálise, in the period March 1996 to March 2000.

November 1996: convection over central Brazil organized itself and interacted with cold fronts coming from the south, however there was no SACZ in action. Normal to above normal rains over the greater part of the country.

December 1996: the SACZ was not in action during the month. Rains above average in part of the South Region and below average in the Northeast, Central-West and North Regions.

January 1997: heavy rains, with hail, in the Southeast Region (including the south of MG), PR, center and coast of SC, caused by SACZ, which acted in two periods. January 2 to 8 : the cloud band extended itself from Central Brazil to the Southeast Region and to the ocean off the coast of ES. A mid-level trough collaborated in intensifying the frontal system, and a High Level Vortex over the Tropical Atlantic collaborated to make the band stationary. January 20 to 29: the band covers a great part of Central Brazil, center and south of the Southeast, extending to the ocean by way of the SP coast. The Chaco Low was more intense than usual and contributed to above normal rainfall over Central Brazil, besides SACZ, a consequence of the organization of convective activity over South America. Belo Horizonte (MG) recorded a total rainfall of $510 \mathrm{~mm}$ in the month.

February 1997: No SACZ events were observed, despite the well-defined pattern of Bolivia High and Northeast Brazil trough (one of the criteria for evaluating if conditions for SACZ are favored). In RS, short waves, convective clusters and cyclonic vortices in the high levels were active and interacted with frontal systems causing rains.

March 1997: SACZ was active on March 1 to 5 and 17 to 23 and caused intense rain in BA. Despite the low frequency of fronts and their weak intensity, two of them coupled with the SACZ producing departures over $300 \mathrm{~mm}$ of rainfall above the normal. 
Lençóis (BA) recorded $41 \mathrm{~mm}$ on the $17^{\text {th }}$ and 93 $\mathrm{mm}$ on the $18^{\text {th}}$; Barra (BA), $117 \mathrm{~mm}$ on the $18^{\text {th }}$, and Vitoria da Conquista (BA) $91 \mathrm{~mm}$ on the $19^{\text {th }}$.

October 1997: there was no SACZ. Intense frontal rains (also MCCs) occurred in RS, with departures of $450 \mathrm{~mm}$. Intense and well defined $\mathrm{El}$ Niño continues. A wave train was observed coming from the Tropical Pacific up to the Brazilian Southeast where it created an anticyclonic anomaly.

November 1997: November 14 to 19, the SACZ organizes a cloud band and tropical convection from Amazonas, Central-West Region and between SP and RJ. The cold fronts, as they moved through the Brazilian Southeast coast, remained semi-stationary due to the presence of a cyclonic vortex in high levels in the Brazilian Northeast during this period.

December 1997: eight frontal systems acted in Brazil and produced above normal rains in the South Region and in the south of the Southeast Region, but there was no SACZ, even though a cold front remained 3 days stalled over Rio de Janeiro. The low level jet coming from the Amazon region down to the south of the country acted almost the whole month.

February 1998: Although satellite images have shown the presence of two stationary fronts over the coast of the state of São Paulo, setting the pattern for a SACZ, "the classic conceptual model is not observed," since rather than the trough over the Brazilian Northeast, an anticyclonic area is observed. Also potentially favorable for a SACZ was a persistent SST (Sea Surface Temperature), above the climatological average, next to the southeast coast. Monthly precipitation in SP state reached departures 60 to $100 \mathrm{~mm}$ above climatological average. Equally in March 1998, no SACZ was observed in accord with the conceptual model.

November 1998: The SACZ occurred from the $20^{\text {th }}$ to the $25^{\text {th }}$, appearing in images oriented NW to SE, from the Amazon region, passing over the Central Region, south coast of BA and ES, extending over the ocean. The cloud band was more compact and uniform over the ocean (extending well offshore RS), and over the border BA/MG. According to the analyses, there was moisture convergence and wind confluence in the lower and middle levels, as well as other factors which contributed to intensification, such as cold air inflow in the rear. Also cooperated the well marked Bolivia High (which intensified convection in Central Brazil) and the High Level Cyclonic Vortex of the Northeast. Although the mean fields indicated further favorable conditions "no more periods of SACZ were observed in accord with the conceptual model" (sic). In spite of above normal convection near the South Pacific Convergence Zone (SPCZ), the greatest remote influences for Brazil proceeded from Central America, as in the month before. The Samuel dam (RO) recovered its discharge (47\% above the average) while Furnas (MG), Marimbondo (MG) and Água Vermelha (MG) stayed 25\% below average. December 1998 had no SACZ.

January 1999: eight frontal systems affected Brazil this month; the $2^{\text {nd }}, 3^{\text {rd }}$ and $4^{\text {th }}$, January 6 to 18 , marked a long period of SACZ, located a little to the south of its climatological position. The cloud band covered the southwest of AM, AC, MT, GO, northeast of MS, southwest of MG, SP, extending towards the Atlantic Ocean around the coast of SP and RJ states. It is pointed out that in this period no Meso-scale Convective Complexes formed over north Argentina, possibly due to deviation of the moisture flow from the Amazon region towards the $S A C Z$ region. February 1999 did not present a SACZ but had heavy rain in the Southeast, associated with coastal low pressure.

October 1999: the SACZ was configured between the $23^{\text {rd }}$ and $31^{\text {st }}$, which is confirmed by the mean Emergent Long Wave Radiation (Figure 5). It acted in the states MT, TO and GO, extending to the Atlantic Ocean by way of the coast of BA. The SACZ development begins with a weak cold front at the coast of BA which intensifies as it interacts with a new front, associated with and extratropical cyclone formed in the south of Brazil on the $25^{\text {th }}$. It is interesting to note that in this period the Bolivia High was poorly defined, and that the drought situation in the Southeast Region worsened, harming agricultural activities (we may add, possibly the rainfall deficit could be tied to a descending branch of the SACZ circulation).

November 1999: La Niña has intensified in relation to October, there were 5 frontal systems (below the average of 7), and the SACZ was configured between the $17^{\text {th }}$ and the $25^{\text {th }}$, its cloud band acting in the states TO, BA north-central MG, extending towards the Atlantic through the coast of BA and ES. The high-level mean circulation (250 $\mathrm{hPa}$ ) presents a good example of teleconnection (Fig. 1.3.1, p. 17), showing the trajectory of a wave train originating in the enhanced convection region north of Australia and that propagates through the South Pacific to the Brazilian Southeast. This latter region had a rainfall deficit, adversely affecting reservoir levels. In Central Brazil also convection was inhibited, a fact which is attributed to the subsidence area associated with SACZ, located further to the north and east.

December 1999: There were two SACZ episodes, in December 8 to 14 and December 16 to 20 , the first one between south BA and north MG, the second between the states of SP, RJ, and south MG. In spite of positive rainfall departures in SP and MG, reservoirs showed negative discharge departures. The fourth cold front of the month contributed to the first episode, as it became stationary after moving 

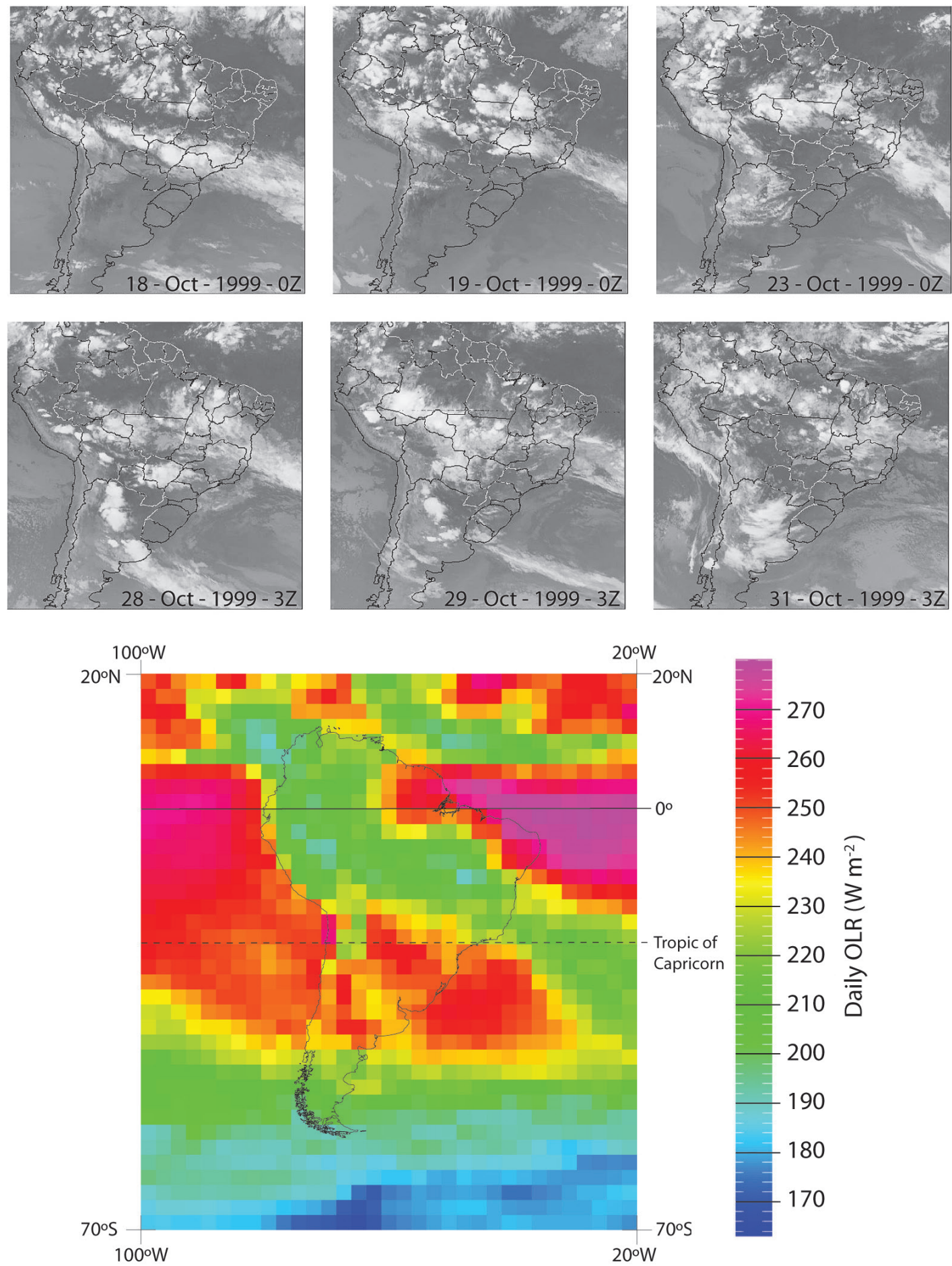

FIGURE 5 - Image constructed with mean values of Outgoing Long Wave Radiation $\left(\mathrm{W} \mathrm{m}^{-2}\right)$ in the period 18 to 31 October 1999, which confirms the SACZ presence, and indicates clearly and precisely its position and extension in the period. The GOES-8 images illustrate the cloud band position for the corresponding dates. Source: CPTEC/INPE satellite image; NCEP-CPC OLWR data. 
from SC in the south to Northeast Brazil while organizing SACZ cloudiness and rains, reinforced additionally by the presence of the subtropical jet. In the second episode, in which the SACZ acted over the states of MT, GO, southern AM and PA, extending towards the Atlantic from the coast of BA, there was the contribution of low-level wind confluence transporting moisture from the Amazon region, a fact confirmed by the moisture convergence map (Figure 6). Another interesting fact observed this month was a teleconnection between South America and South Africa, in which convection over the north of Brazil seemed to stimulate a Rossby wave train connecting the two continents.
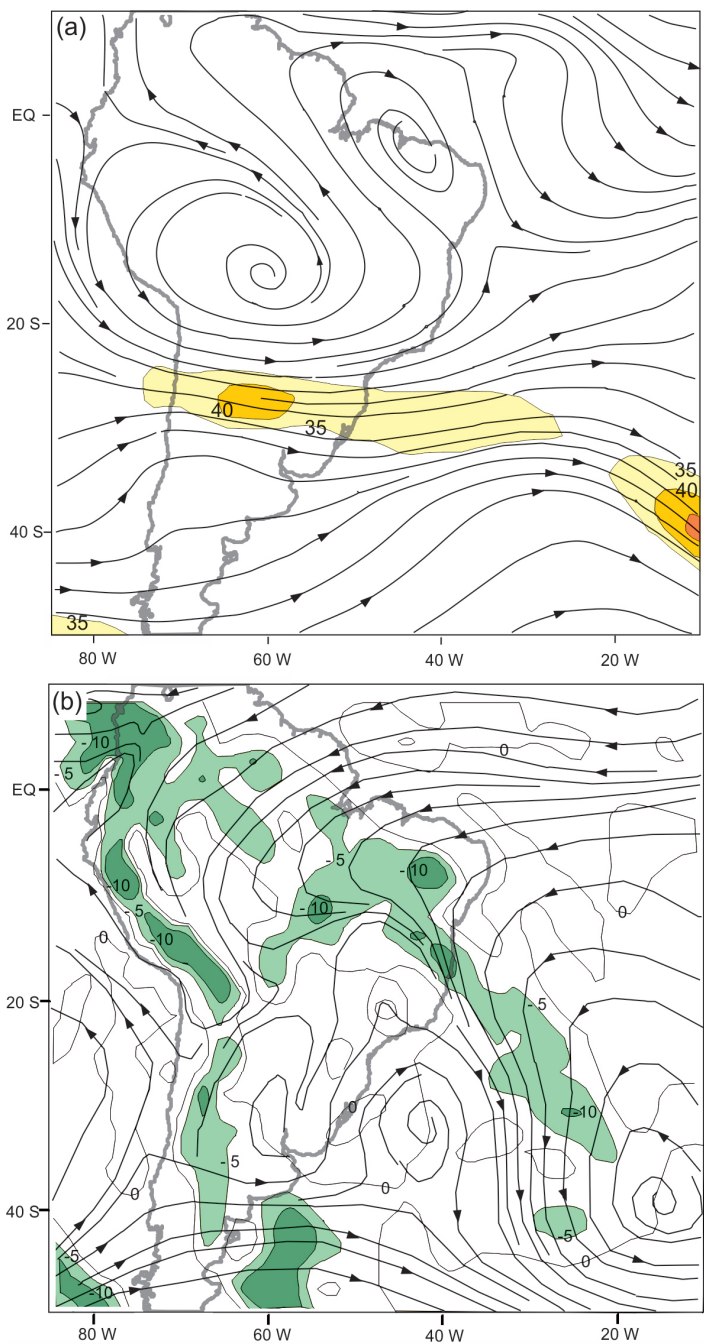

FIGURE 6 - Mean fields for December 1999. (a): Mean streamlines and isotachs $\left(\mathrm{m} \mathrm{s}^{-1}\right)$ at $250 \mathrm{hPa}$. (b): Mean humidity convergence $\left(\mathrm{kg} / \mathrm{kg}^{*} \mathrm{~s}^{-1}\right)$ and mean streamlines at $925 \mathrm{hPa}$ (near surface level). Adapted from Climanálise, v. 14, n. 12, 1999, p. 32.
January 2000: a strong La Niña (anomaly of SST $-3{ }^{\circ} \mathrm{C}$ ). There were five weak frontal systems, one of them contributing to the formation of the first of two SACZ episodes in the month and which caused intense rains in southern $\mathrm{MG}$, coast of SP and RJ, between the $1^{\text {st }}$ and the $8^{\text {th }}$. Campos do Jordão (SP) recorded a total monthly rainfall of $439 \mathrm{~mm}$, Itajubá (MG) $374 \mathrm{~mm}$ and Resende (RJ) $287 \mathrm{~mm}$. The second SACZ occurred between the $21^{\text {st }}$ and $24^{\text {th }}$, acting over a great part of $\mathrm{TO}$ and $\mathrm{MG}$, extending towards the Atlantic from the coast of BA. In this second episode, in addition of moisture convergence in low levels, there was a $500 \mathrm{hPa}$ trough which collaborated to intensify convection. In the north and northeast of $\mathrm{MG}$, the rains contributed to increase Sobradinho's level (BA), but it is still low. Neither in the Southeast or at reservoirs a little to the north such as Três Marias (MG), Emborcação (GO) and Itumbiara (MG) was there an improvement in the negative anomalies. As for S. Simão (GO) and Furnas (MG), and in Marimbondo (MG) and Água Vermelha (MG), the flow improved, reaching from 30 to $73 \%$ above the long-term mean.

February 2000: the SACZ presented itself between the $6^{\text {th }}$ and the $13^{\text {th }}$ with a semistationary band over MT, GO and MG extending towards the Atlantic Ocean from the coast of ES. But what marked the month were some heavy rains in the Southeast region, especially in SP state in the last week of the month, while little convection was recorded in the North, over $\mathrm{AM}, \mathrm{AC}$ and RO. The end of the SACZ active period was signaled by the arrival of a new frontal system that determined the undulation of the cloud band and the termination of the phenomenon. In March 2000 the SACZ was not observed, even though there were 9 frontal systems in the month whereas the average is 6 .

\section{PARTICIPATION OF THE SACZ IN THE RAINFALL REGIME}

The above cited monthly summaries from Climanálise clearly show the SACZ association with intense precipitation episodes during the Brazilian summer. However, they also show that the SACZ presence is not a sufficient condition for the occurrence of significant precipitation in this country's main rainfall season, between October and March, and can be totally absent, even two months in a row. We now cite other studies which contribute to define the SACZ's relative importance in this country's rainfall regime. 
GUIMARÃES et al. (2008) analyzed 53 cases of SACZ that occurred between 1998 and 2007,18 of them associated with landslides in the Brazilian southeast region, and found the following frequencies for landslides: December 4, January 6, February 2, March 4 . The most prolonged rainy period and with SACZ occurred between 27 December 2006 and 16 January 2007.

ALVES FILHO (2001) analyzed 11 largeimpact floods in São Paulo's Metropolitan Region in the decade 1982-1991, in which we counted the following monthly frequencies: December 1, January 2, February 2, March 1, April 1, June 2, July 1, and September 1. Prevailing genetic processes were stationary fronts getting reinforcement from a new polar invasion, and extratropical cyclonic activity. But in the March 19, 1991 flood, when a rain gage in Santo André (SP) recorded $176.2 \mathrm{~mm}$ of rain in 1 hour, there was SACZ participation "forming convective nuclei of great intensity", according to the author, based on data from the Ponte Nova weather radar. There were 17 dead in the capital city in this episode, besides 33 dead from leptospirosis in the following days.

The weather radar that we just mentioned has a great potential, not much used yet, for studying SACZ and its composition and behavior. A study on classification of meteorological systems made with the Ponte Nova radar (SANTOS SILVA et al. 2009) refers to the SACZ as belonging the "Scattered Bands" group and shows (in its Fig. 6, p. 299) data from an episode in January 2000 observed over the Paraíba Valley, and north coast of SP state, which was followed by radar during over 20 hours, between the $2^{\text {nd }}$ and $3^{\text {rd }}$ of the month. The images are given in the form of precipitation rates, in millimeters per hour. The band contained convective and stratiform precipitation areas. In addition to "Scattered Bands" the Ponte Nova radar recognizes 4 more types of precipitation systems (SANTOS SILVA et al. 2009): isolated convection, sea breeze, instability lines, and cold fronts. The events themselves are classified according to precipitation intensity in Convective and Stratiform.

Although SACZ studies in Brazil have been focused on its terrestrial branch and on its close relationship with Amazon convection, it is worth recalling that historically, since Streten's work in 1973, this type of convergence zone and its counterparts in the Pacific and Indian constitute largely oceanic phenomena, which it is where they reach their greatest expression and extension (see figs. 1 and 3 in STRETEN 1973, p. 487 and p. 489, respectively). For this reason (beside others), a paper should gain relevance: authored by Lucimar Luciano de Oliveira and published in the Hydrographic Annals of 1981 (OLIVEIRA 1981), it concerns the South Atlantic frontal zone, and is based on analyses of satellite images and surface and upper air data from the Trindade Island Oceanographic Station (POIT), for the period 1966-1978. The POIT was created as a Brazilian contribution to the International Geophysical Year (1957-58), an enterprise that as a national contribution to world scientific programs has a parallel, in regard to significance and continuity, in the establishment in 1984 of the Comandante Ferraz Antarctic Station. However, Oliveira does not distinguish the SACZ from fronts, grouping both in a common class of frontal convergence zone, which recalls the manner in which the subject was treated by Japanese researchers, as they proposed different terms for the Baiu, also the object of controversy (the Chinese classify Baiu as a tropical frontal zone, some Japanese propose that in the east of the islands it be classified as a polar front zone) (KODAMA 1992, p. 814, footnote). We cite from Oliveira's paper the following statistical data for the SACZ season October to March of mean rainfall and frequency (in \%) of passages of frontal convergence zones observed at POIT in the period 1966-1978 (Table 1).

TABLE 1 - Mean of precipitation and relative frequency of passages of frontal convergence zones observed in POIT in the period 1966-1978. (Source: OLIVEIRA 1981).

\begin{tabular}{lllllll}
\hline & Oct & Nov & Dec & Jan & Feb & Mar \\
\hline Precipitation (mm) & 55.5 & 119.5 & 57.0 & 62.0 & 40.0 & 73.6 \\
$\begin{array}{l}\text { Convergence zones } \\
\text { (Rel. Freq. \%) }\end{array}$ & 3.4 & 3.4 & 4.2 & 4.5 & 5.9 & 3.4 \\
\hline
\end{tabular}


The main purpose of Oliveira's paper (1981) is to contribute to an evaluation of the influences of such convergence zones on the rainfall regime of the Brazilian Northeast. By means of a comparative study of the monthly brightness values (an indication of presence of clouds associated with rain) for the semester December to May observed in three different regions (Northeast, South and Oceanic), Oliveira shows (see his fig. 4.13 and also 4.10) a kind of see-saw effect: in a dry semester in the Northeast (1971-72), clouds indicate greater rainfall in the Brazilian southeast coast and in the Trindade oceanic area, and contrarily, in a rainy semester in the Northeast (1973-74), less rain in the southeast coast and oceanic area.
This paper by OLIVEIRA (1981) shows, further (Figure 7), an interesting conceptual model of interaction between the ITCZ and the South Atlantic Frontal Convergence Zone, in spring and autumn. We recommend reading it as a review of theoretical concepts about air masses, polar front, frontal systems and cyclogenesis, westerly waves, etc.

The data for Trindade are also of interest for the study of SACZ, as indicative of the behavior of the South Atlantic Subtropical High, also known as "Trindade High", in as much as it is the moist wind circulation of east and north components along the southwest side of the Subtropical High that sustains the SACZ (NINOMIYA 2007).

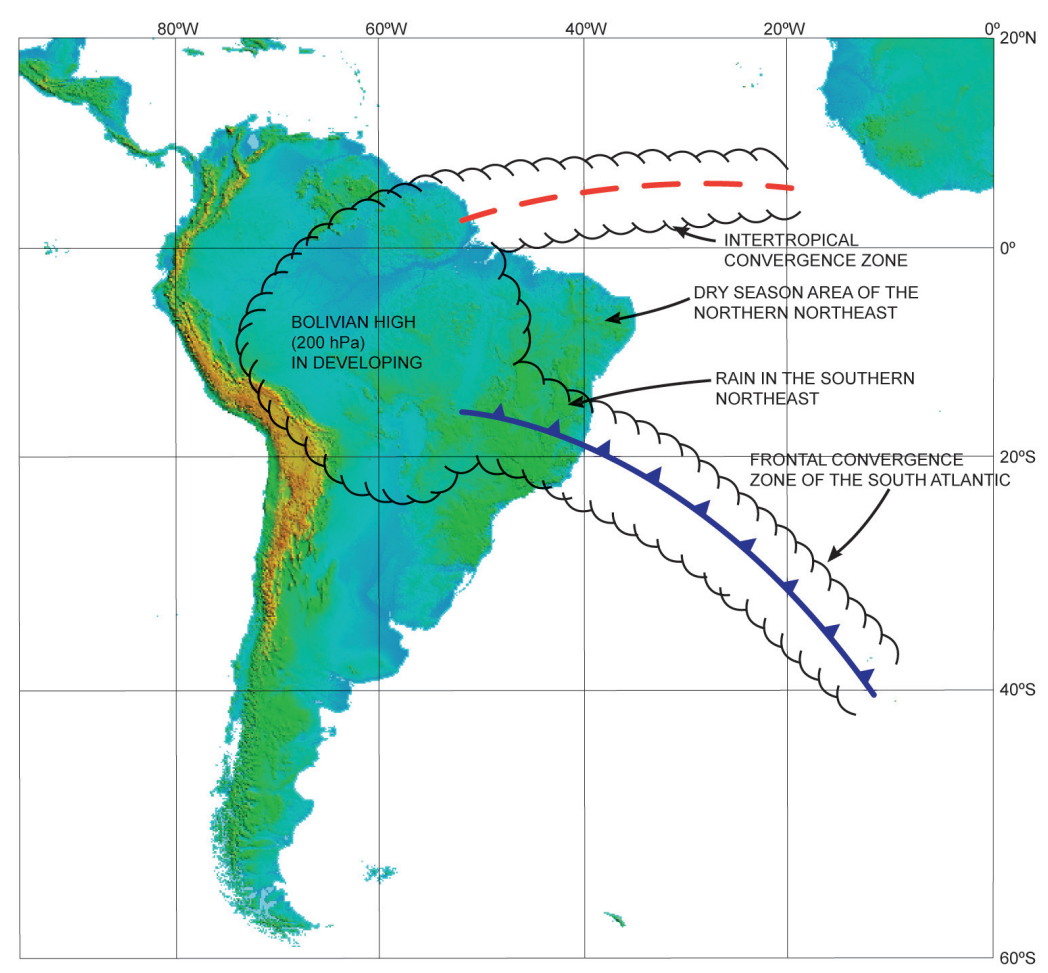

FIGURA 7 - Conceptual model of interaction between the ITCZ and the South Atlantic Frontal Convergence Zone in spring. Adapted from OLIVEIRA (1981); Digital Terrain Model from NASA/USGS.

\section{REMOTE INFLUENCES AND SACZ VARIABILITY}

One of the most complex aspects in studying this subject is the high variability of the SACZ in time and space, in different scales, and different combinations of factors and couplings (CARVALHO \& JONES 2009). Position and activity can vary from year to year, within the same season (spring and summer), oceanic or continental branch, with El Niño or La Niña, with Madden-Julian oscillation, Pacific-South America 
oscillation, sea surface temperature anomalies, etc. This while the cause or exact mechanisms are still unknown; here we will touch on only some topics, emphasizing remote influences (teleconnections); recalling the existence of a vast literature on the subject, including several high-level Brazilian papers. We quote from one of them (CARVALHO \& JONES 2009, p. 109) the following conclusion:

"This review shows that a complete understanding of the extension, variability, and impact of SACZ on South America depends on comprehending the interactions between tropics and extratropics and on the complexity of the relationships between coupled phenomena in diverse spatial and temporal scales".

In El Niño years the SACZ appears to be stronger and doubles in frequency over the ocean. Note that a stronger SACZ promotes extreme precipitation all over São Paulo state, while a weak SACZ and displaced toward the ocean favors extreme rains mainly along Serra do Mar (CARVALHO \& JONES 2009). The most intense convection in oceanic SACZ occurs in association with the propagation of Rossby wave trains from mid latitudes and connected with tropical intraseasonal disturbances (CARVALHO \& JONES 2009). In La Niña years, SACZ behavior is more variable and generates a cyclonic circulation in the south which extends to the continent; a comparative study of SACZ in El Niño and La Niña and normal years appears in FERREIRA et al. (2004).

The Madden-Julian 30-60 day oscillation originates in the high tropical troposphere and propagates downwards, polewards and eastwards (GOSWAMI \& SHUKLA 1984, CASARIN \& KOUSKY 1986, KAYANO \& KOUSKY 1996), configuring a direct zonal circulation cell which modulates tropical convection. It can displace the SACZ farther to the north; combined with the PSA (Pacific South America, another teleconnection pattern), it may even create a SACZ (CUNNINGHAM \& CAVALCANTI 2006). It is an important source of large-scale intraseasonal variability in the tropical zone.

\section{ADDITIONAL REMARKS}

As a meteorological organism, a SACZ can be viewed as a kind of chimera, in the sense that it is a heterogeneous combination of diverse elements: sometimes it looks, from structure and behavior like an ultra-long Rossby wave or a
Kelvin wave (that propagates fast from west to east), a monsoon front, etc. The concept appears to suffer from an identity crisis ("To be or not to be a SACZ?"); in synoptic charts, the SACZ is drawn very similarly as an ITCZ (the so called "big worm"). Somewhat similar is the manner in which phenomena like El Niño or SACZ are denominated when missing, such as a "Non-El Niño year" and a "NSACZ episode"; and by the way both kinds of such "no-show" episodes demand studies or explanations.

Certain basic aspects about the nature and formation of SACZ await theoretical explanation. Little is known about the process of great interaction which is observed between mid and tropical latitude along the SACZ (FERREIRA 1992). Why the maximum in kinetic energy appears at the $400 \mathrm{hPa}$ level and not higher, nobody knows (Carlos Afonso Nobre, conference speech, 1992). Where is the latent heat liberated in convection going? Why the SACZ remains stationary: an effect of convection, of the Andes, of liberation of latent heat? (Carlos Afonso Nobre, conference speech, 1992). But we know that liberation of latent heat organizes the circulation especially above, in the higher levels (in a hurricane, lower down) (Pedro Leite Silva Dias, conference speech, 1992). Thermodynamic processes acting on SACZ require further studies, such as the continual generation of convective instability (KODAMA 1993). It may be fit to recall that the lifting of a whole layer generates much more instability than the lifting of a parcel, especially if the base is moist and the top dry.

The SACZ's share in the rainfall regime largely limited to the summer season - is variable and debatable. Its importance is not denied, but the part due to other meteorological organisms should never be forgotten, especially the frontal systems, which act all year long. May I cite as pertinent examples two exceptionally intense precipitation events in São Paulo state and in the summer, which I lived closely and analyzed in depth, and which were reported in accessible meteorological language in the publications mentioned (VILLELA 1959, 1977).

a) In January 1959, rains that had been falling torrentially in central and north SP, intensified overnight Sunday the $18^{\text {th }}$ to Monday $19^{\text {th }}$. Floods caused greater devastation in Catanduva (which recorded a $57 \mathrm{~mm}$ rainfall in 24 hours) and Jaboticabal. The greatest amount 
was $130 \mathrm{~mm}$ at Roboré in Bolivia. What we call attention for was the exceptional extension of the cold front pointed out as the main factor responsible for the rains, oriented in the NNWSSE direction "from the north of Bolivia all the way down to Antarctic waters near the South Orkney islands". This according to the synoptic chart we analyzed at the Real-Aerovias airlines. We made there a particular effort to collect data by radiotelegraphy, unavailable otherwise, from ships and Antarctic bases and which were felt to improve the quality of synoptic analysis and weather forecasting for aviation. (For a more modern usage of radio transmissions as sources of weather data, see VILLELA 1991).
Radiosonde data for São Paulo at 21 hours of the $18^{\text {th }}$ showed that "the pre-frontal warm air mass was saturated up to about a height of $8 \mathrm{~km}$ ", the wind at $500 \mathrm{hPa}$ being from 280 degrees at 15 knots. The synoptic charts showed yet "a greater convergence of winds and tendency to form a small low pressure center" just over the area most affected by the storms (Figure 8) (VILLELA 1959).

b) January 1977 had record rains and floods in all South-Central Brazil and will go down in history for the burst of two CESP dams in the river Pardo and landslides in Teresópolis (RJ) that killed 33 people. We followed the evolution from the Air Force Academy at Piraçununga, being in charge

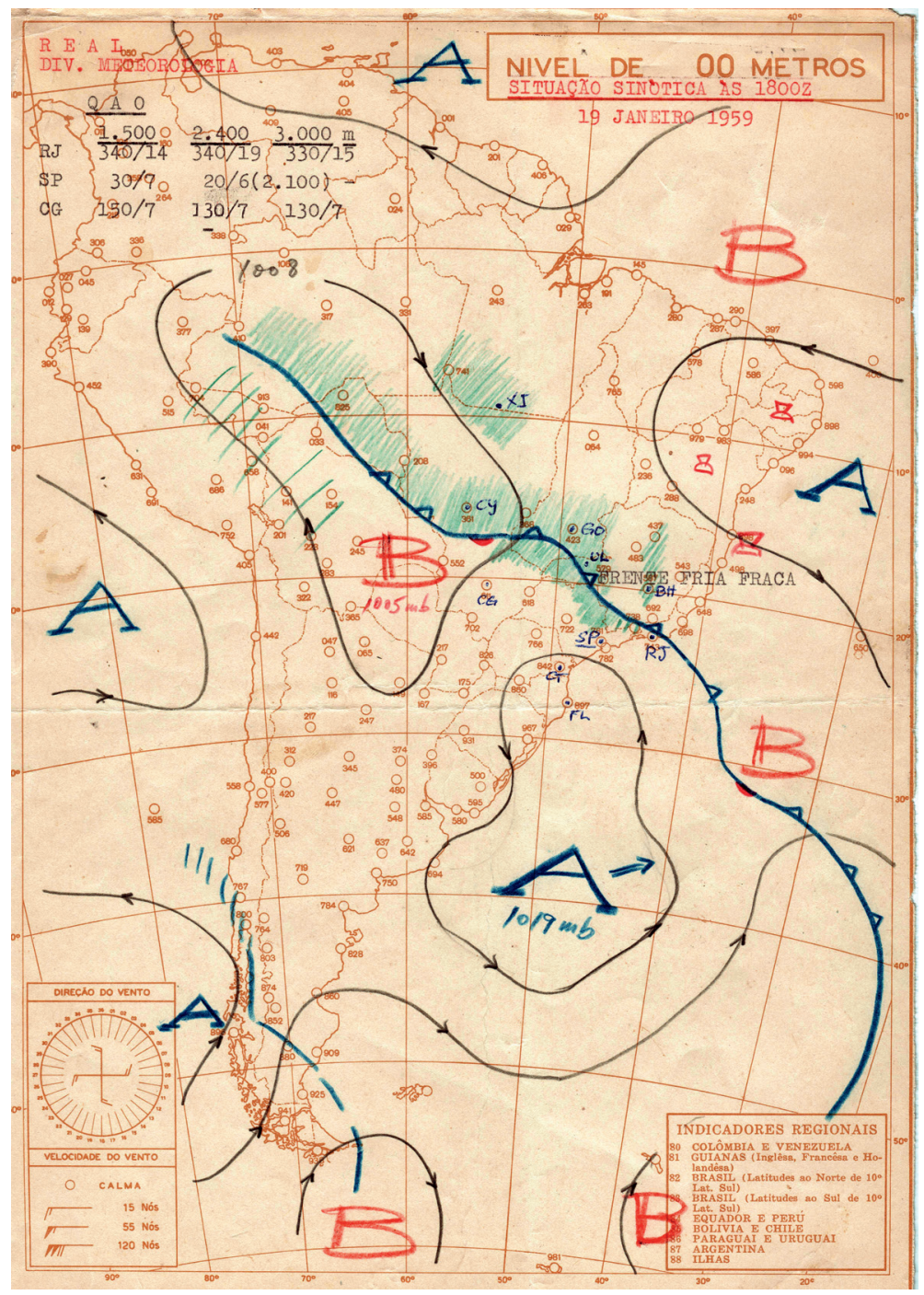

FIGURE 8 - Original synoptic chart for $19^{\text {th }}$ January $195918 Z$ (by Rubens J. Villela to REAL Aerovias Airlines). "A" = H (High pressure), "B" = L (Low pressure). 
of meteorological support to the XIX Brazilian Soaring Championship. We quote directly from parts of a published report we wrote at the time (VILLELA 1977, 1984): "Almost daily rains, sometimes incessant but generally in the form of thunderstorms and showers, often torrential and striking at varied times of the day (including at dawn), characterized January of 1977 over a wide area of South-Central Brazil, spreading to the West and Central regions. Low barometric pressure and winds from the north prevailed, configuring an anomaly of tropical nature in atmospheric circulation, in part similar to the one that occurred in January 1970, also associated with great floods in SP (...) (...). Front no. 3 passes São Paulo at night on the $18^{\text {th }}$ to the $19^{\text {th }}$, with strong SE wind. But in the east central area of the state, the front does not advance and the wind blows from the NW, creating a kind of 'warm sector' in the front, with a distinct cyclonic circulation (...) and low pressure. Convergence in the center of the cyclonic area, where the front suffers a bend or wave, enhances the liberation of instability of the warm and moist mass, with the well known results (...). The capital of SP is taken by surprise at the dawn of Wednesday the $19^{\text {th }}$ by an incessant and prolonged rain that accumulated $103 \mathrm{~mm}$ at an MA station in a 24hour period (...). But the focus of the precipitation occurs in the area of São José do Rio Pardo (SP), a true cloudburst - in the terms of the official CESP bulletin - beginning at noon of the $19^{\text {th }}$. Five hours later the Pardo river had already risen 6 to 8 meters. From 20 hours of the $19^{\text {th }}$ to 4 hours of the $20^{\text {th }}$ the rains increased even more, totaling according to semi-official data, between 160 and $230 \mathrm{~mm}$. The ground shakes and dams "Euclides da Cunha" and "Salles Oliveira" (Limoeiro) burst, releasing 20 million cubic meters of water (...).

\section{FINAL CONSIDERATIONS}

The South Atlantic Convergence Zone, together with its two Pacific and Indian counterparts, constitutes a new class of large-scale phenomenon that occurs in the Earth's atmosphere, during the period from late spring to late summer. They are thus basically a product of heat, either solar or from condensation of water vapor. In meteorological satellite images, which led to their discovery in the 1970s, these zones can show up, in their entirety, as long and persistent convective and stratiform cloud bands, extending diagonally from the subequatorial to the sub-polar regions.
On the other hand, a zone in a given month of the season can be totally absent from an ocean or continent. Even without a definitive explanation for the phenomenon, the term ZCAS has definitely entered Brazilian's meteorological lexicon, in view of its evident associations with the tropical rainfall regime (see Participation of the SACZ in the rainfall regime above), both over the ocean as over the adjacent South American continent, including the Amazon region. In part, the SACZ is a result of the interaction between the South Atlantic Subtropical High (the "Trindade High") and the fronts and westerly systems from mid latitudes. It is known that zones of the SACZ type create their own circulation, reinforcing and self-sustaining the phenomenon; an ascending branch of moist and converging winds feeds it, while a descending counterpart creates subsidence and dissipation of clouds in neighboring regions, to the north and to the south of the band.

The frontal systems are also elongated zones of clouds and precipitation, and convergence of winds; however, contrary to a SACZ, frontal structure presents a marked contrast in density and humidity (and in potential temperature), whereas there is no such contrast in SACZ, within its internal structure, everywhere moist (as measured by high values of equivalent potential temperature). On the other hand, the frontal systems are always present (3 to 8 per month in Brazil on the average), while SACZ, in certain months, even in summer, can "shine by being absent", as mentioned before. And to confound us further, in recent years, a new term has appeared in CPTEC's bulletins: ZCOU or Humidity Convergence Zone, still lacking a definition but which seems to signal to a potential SACZ. Naturally, facts such as these reflect in part our lack of knowledge on the formation processes of the SACZ and compromise possible forecasts of rain, for instance, from a diagnostic of a SACZ situation: after all, to satisfactorily characterize a SACZ, by present rules, it is necessary to wait for 4 days, and numerical models capable of dealing with remote influences, among others, are still at fault. On the other hand, models are getting ever better, and only them would have the capacity to deal with the global multi-variables that influence the formation and behavior of SACZ and its counterparts. It is Vernon Kousky, our former, esteemed professor and benefactor of modern Brazilian synoptic meteorology who recommends (CASARIN \& KOUSKY 1986): The monitoring of Emergent Long Wave Radiation in the region of 
Indonesia and the South Pacific Convergence Zone could provide an important contribution to the improvement of the quality and length of weather forecasting in Brazil.

\section{ACKNOWLEDGEMENTS}

I thank the two reviewers and editors of the Revista do Instituto Geológico for their helpful comments.

\section{REFERENCES}

ALVES FILHO, A.P. 2001. As enchentes. In: J.R. Tarifa \& T.R. Azevedo (org.) Os climas na cidade de São Paulo: teoria e prática. São Paulo, GEOUSP - Coleção Novos Caminhos - 4, Programa de Pós-Graduação em Geografia, Laboratório de Climatologia e Biogeografia, Departamento de Geografia, FFLCH - USP, p. 94-111.

AMERICAN METEOROLOGICAL SOCIETY. 2000. Glossary of Meteorology. AMS, Boston, $2^{\text {nd }} e d ., 855 \mathrm{p}$.

CALHEIROS, R.V.; SILVA DIAS, P.L. 1988. Como prever melhor. Climanálise, 3: 31-32.

CARVALHO, L.M.V.; JONES, C. 2009. Zona de convergência do Atlântico Sul. In: I.F.A. Cavalcanti, N.J. Ferreira, M.G.A.J. Silva, M.A.F. Silva Dias (org.) Tempo e Clima no Brasil. São Paulo, Oficina de Textos, p. $95-$ 109.

CASARIN， D.P.; KOUSKY， V.E. 1986. Precipitation anomalies in the Southern part of Brasil and variations of the atmospheric circulation. Revista Brasileira de Meteorologia, 1: 83-90.

CPTEC/INPE - CENTRO DE PREVISÃO DE TEMPO E ESTUDOS CLIMÁTICOS/ INSTITUTO NACIONAL DE PESQUISAS ESPACIAIS. 1996-2000. Climanálise: Boletim de monitoramento e análise climática. Cachoeira Paulista, CPTEC-INPE. Mensal. (Selected months, 1996-2000, as indicated in the text).

CUNNINGHAM, C.A.C.; CAVALCANTI, I.F.A. 2006. Intraseasonal modes of variability affecting the SACZ. International Journal of Climate, 26(9): 1165-1180.
ERICKSON, C.O.; WINSTON, J.S. 1972. Tropical storm, mid-latitude, cloud-band connections and the autumnal buildup of the planetary circulation. Journal of Applied Meteorology, 29(1): 23-36.

FERREIRA, N.J.; SANCHES, M.; SILVA DIAS, M.A.F. 2004. Composição da Zona de Convergência do Atlântico Sul em períodos de El Niño e La Niña. Revista Brasileira de Meteorologia, 19(1): 89-98.

FRANK, W.M. 1983. The structure and energetics of the east Atlantic Intertropical Convergence Zone. Journal of Atmospheric Sciences, 40(8): 1916-1929.

GAN, M.A.; SANTOS, L.F.; LIMA, J.R.A.; AFONSO, J.M.S.; SILVA, A.B. 2016. Monção da América do Sul. Climanálise, Edição Comemorativa 30 anos: 1-6.

GOSWAMI, B.N.; SHUKLA, J. 1984. Quasiperiodic oscillations in a symmetric GCM. Journal of Atmospheric Sciences, 41(1): 20-37.

GUIMARÃES,J.M.; CHOU,S.C;DERECZYNSKI, C.P. 2008. Análise de casos de ZCAS utilizando técnicas de agrupamento. In: SBMET, CONGRESSO BRASILEIRO DE METEOROLOGIA, 15, São Paulo, Coletânea de trabalhos, CD-ROM.

KAYANO, M.T.; KOUSKY, V.E. 1996. Tropical circulation variability with emphasis on interannual and intraseasonal time scales. Revista Brasileira de Meteorologia, 11(1/2): 6-17.

KODAMA, Y. 1992. Large-scale common features of subtropical precipitation zones (the Baiu frontal zone, the SPCZ, and the SACZ). Part I: Characteristics of subtropical frontal zones. Journal of the Meteorological Society of Japan, 70(4): 813-835.

KODAMA, Y. 1993. Large-scale common features of sub-tropical convergence zones (the Baiu frontal zone, the SPCZ, and the SACZ). Part II: Conditions of the circulations for generating the STCZs. Journal of the Meteorological Society of Japan, 71(5): 581610.

NIETO-FERREIRA, R. 2011. The role of cold fronts in the onset of the monsoon 
season in the south Atlantic convergence zone. Quarterly Journal of the Royal Meteorological Society, 137(657, Part B): 908-922.

NINOMIYA, K. 1984. Characteristics of Baiu front as a predominant subtropical front in the summer northern hemisphere. Journal of the Meteorological Society of Japan, 64: 409-429.

NINOMIYA, K. 2007. Similarity and difference between the South Atlantic Convergence Zone and the Baiu frontal zone simulated by an AGCM. Journal of the Meteorological Society of Japan, 85(3): 277-299.

OLIVEIRA, L.L. 1981. Zonas de convergência no Atlântico Sul e suas influências no Regime de precipitação no Nordeste do Brasil. Anais Hidrográficos, T. XXXVIII: 141-192.

QUADRO, M.F.L.; PEZZI, L.P.; ROSA, E.B. 2016. O Climanálise e o monitoramento da ZACAS nos últimos 30 anos. Climanálise, Edição Comemorativa 30 anos: 19-25.

REBOITA, M.S.; GAN, M.A.; ROCHA, R.P.; AMBRIZZI, T. 2010. Regimes de precipitação na América do Sul: uma revisão bibliográfica. Revista Brasileira de Meteorologia, 25(2): 185-204.

SANT'ANNA NETO, J.L. 2015. As Matrizes da Construção da Climatologia Geográfica Brasileira. In: C.A.F. Monteiro, J.L. Sant'Anna Neto, F.A. Mendonça, J.A. Zavattini (orgs.) A construção da climatologia geográfica no Brasil. Campinas, Alínea Editora, p. 25-33.

SANTOS SILVA, F.D.; PEREIRA FILHO, A.J.; HALLAK, R. 2009. Classificação de sistemas meteorológicos e comparação da precipitação estimada pelo radar e medida pela rede telemétrica na bacia hidrográfica do Alto Tietê. Revista Brasileira de Meteorologia, 24(3): 292-307.

SATYAMURTI, P.; RAO, V.B. 1988. Zona de Convergência do Atlântico Sul. Climanálise, 3: 31-35.

SATYAMURTY, P.; NOBRE, C.A.; SILVA DIAS, P.L. 1998. South America. In: D.J. Karoly \& D.G. Vicent (eds.) Meteorology of the Southern
Hemisphere. American Meteorological Society, Meteorological Monographs, 27(49): 119-139.

SAUCIER, W.J. 1969. Princípios de Análise Meteorológica. Ao Livro Técnico, Rio de Janeiro, 462 p.

SCHWERDTFEGER, W. 1951. La depresión térmica del noroeste argentino. Anales de la Sociedad Cientifica Argentina, tomo CLT: 255.

SILVA DIAS, M.A.F; JUSTI DA SILVA, M.G.A. 2009. Para entender tempo e clima. In: I.F.A. Cavalcanti, N.J. Ferreira, M.G.A.J. Silva, M.A.F. Silva Dias (orgs.) Tempo e Clima no Brasil. São Paulo, Oficina de Textos, p. 15-21.

SILVA DIAS, P.L. 1985. A preliminary study of the observed vertical mode structure of the summer circulation over tropical South America. Tellus, 37A(2): 185-195.

SILVA DIAS, P.L.; SCHUBERT, W.H.; DE MARIA, M. 1983. Large-scale response of the tropical atmosphere to transient convection. Journal of Atmospheric Sciences, 40(11): 2689-2707.

STRETEN, N.A. 1973. Some characteristics of satellite-observed bands of persistent cloudiness over the Southern Hemisphere. Monthly Weather Review, 101(6): 486-495.

TARIFA, J.R., AZEVEDO, T.R. 2001. Os climas na cidade de São Paulo - teoria e prática. GEOUSP - Coleção Novos Caminhos - 4, Programa de Pós-Graduação em Geografia, Laboratório de Climatologia e Biogeografia, Departamento de Geografia, FFLCH - USP, $199 \mathrm{p}$.

VILLELA, R.J. 1959. As inundações da Alta Araraquarense e Paulista. O Estado de São Paulo (Suplemento Agrícola), 18/2/59.

VILLELA, R.J. 1960. Tiros I-Precursor do sistema mundial de satélites meteorológicos. Boletim da Sociedade Interplanetária Brasileira, dezembro de 1960: 7-9.

VILLELA, R.J. 1972. Meteorologia Descritiva. Apostila do curso de pós-graduação em Meteorologia Aplicada, Escola de Engenharia de São Carlos - USP - Departamento de Vias de Transporte e Topografia, São Carlos, 48 p. (manuscrito inédito). 
VILLELA, R.J. 1975. Relação entre a evolução do tempo no Brasil e as condições Sinóticas na Antártida. IV Relatório Semestral $\left(2^{\circ}\right.$ semestre de 1974) ao CNPq do bolsista Rubens Junqueira Villela - Proc. 1260/72, pesquisador-assistente Nível B, IAG-USP, $31 / 1 / 75$.

VILLELA, R.J. 1977. Chuvas e cheias recordes em todo o Centro-Sul. Correio Agro-Pecuário (Editora Joruês, S. Paulo), $1^{\text {a }}$ quinzena de fevereiro de 1977, p. 9.

VILLELA, R.J. 1984. Fenômenos meteorológicos relacionados com a ocorrência de cheias na região Sul e Sudeste. In: SEMINÁRIO SOBRE CONTROLE DE CHEIAS, MME/ DNAEE/DCRH, UCPR/ISAM, Curitiba, 2023/8/1984, 35 p. (manuscrito inédito).

VILLELA, R.J. 1991. Radio weather transmissions in the Antarctic. Polar Record, 27(161): 103114.

VILLELA, R.J. 2009. Por dentro do 'poço negro'. Aeromagazine, 16(182): 36-38.

VILLELA, R.J. 2017. Operação Otsu (Japão) Relatório de fechamento para Tunikito Corp. São Paulo, 17/5/17.

\section{Author's address:}

Rubens Junqueira Villela - Instituto de Astronomia, Geofísica e Ciências Atmosféricas, Universidade de São Paulo (IAG/USP), Rua do Matão, 1226, Cidade Universitária, CEP: 05508-090, São Paulo, SP, Brasil.E-mail:rjvillela@gmail.com

Manuscript submitted in 20 August 2017, accepted in 23 December 2017. 